\title{
Law Students' Perceptions about Online Instruction of Professional Foreign Language Course during Covid-19 Pandemic
}

\section{Hukuk Öğrencilerinin Covid-19 Pandemisi Sırasında Çevrimiçi Mesleki Yabancı Dil Kursu Öğretimine İlişkin Görüşleri}

\author{
Ferzan ATAY ${ }^{1}$, Amirreza MAHMOUDI' ${ }^{2}$ \\ Article History: $\quad$ Received: 28.12.2020 / Accepted: 18.02.2021 \\ Makale Geçmişi: Geliş: 28.12.2020 / Kabul: 18.02.2021
}

Doi: $\underline{\text { https://doi.org/10.47806/ijesacademic.848417 }}$

\begin{abstract}
This study examined Law students' perceptions about integrating technology and online education of Professional Foreign Language Course during COVID-19 pandemic. For this aim, 91 third-year and 86 fourth-year Law students were selected to participate in this study. The convenience sampling method was used when selecting the participants. The participants were required to answer an open-ended questionnaire regarding their perceptions about online education and its differences with traditional education. By collecting and analyzing the qualitative data, it was revealed that $77 \%$ of the participants had negative attitudes towards online education. These participants reported that online education was challenging for them. The most challenging factors for the participants of this study were lack of self-reliance and self-confidence, being stressful about losing family members, lack of immediate feedback from their instructor, being interrupted by their family members, lack of concentration because of distraction by phone and other online applications, having technical problems, being stressful because of financial problems, and lack of group work. The findings also illustrated that $33 \%$ of the participants had positive attitudes towards online education of their course and found it satisfying in terms of education. Most of these participants stated that they could feel themselves as an independent learner, they did not waste their time and money, and they had more contact with their instructor. They also added that online education brought technological facilities to their course and they felt themselves less stressful and more confident.
\end{abstract}

Key Words: Online education, law students, professional foreign language course, Covid-19 pandemic

\section{Özet}

$\mathrm{Bu}$ çalışma, COVID-19 salgını sırasında Hukuk öğrencilerinin teknoloji ile Profesyonel Yabancı Dil Kursu'nun çevrimiçi öğretimini entegre etme konusundaki algılarını incelemiştir. $\mathrm{Bu}$ amaçla, 91 üçüncü sinıf ve 86 dördüncü sinıf Hukuk öğrencisi bu çalışmaya katılmak üzere seçilmiştir. Katılımcıların seçiminde uygun örnekleme yöntemi kullanılmıştır. Katılımcılardan çevrimiçi eğitim hakkındaki görüşleri ve geleneksel eğitimden farklılıkları ile ilgili açık uçlu bir anketi yanıtlamaları istenmiştir. Nitel verilerin toplanması ve analiz edilmesi sonucunda katılımcıların \%77'sinin çevrimiçi eğitime yönelik olumsuz tutumları olduğu ortaya çıkmıştır. Bu katılımcılar, çevrimiçi eğitimin kendileri için zor olduğunu bildirmiştir. Bu çalışmanın katılımcıları için en zorlayıcı faktörler, özgüven ve kendine güven eksikliği, aile üyelerini kaybetme konusunda stresli olmaları, eğitmenlerinden anında geri bildirim alamaması, aile üyeleri tarafindan kesintiye uğraması, telefon ve diğer çevrimiçi uygulamaların nedeniyle konsantrasyon eksikliği, teknik sorunlar yaşama, finansal sorunlar nedeniyle stresli olmak ve grup çalışmasının olmamasıdır. Bulgular ayrıca katılımcıların \%33'ünün kurslarının çevrimiçi eğitimine karş1 olumlu tutumları olduğunu ve bu eğitim araçlarını tatmin edici bulduklarını göstermiştir. $\mathrm{Bu}$ katılımcıların çoğu, kendilerini bağımsız bir öğrenci olarak hissedebildiklerini, zamanlarını ve paralarını boşa harcamadıklarını, eğitmenleriyle daha fazla iletişim kurduklarını belirtmişlerdir. Ayrıca, katılımcılar çevrimiçi eğitimin derslerine teknolojik olanakları getirdiklerini ve sonunda kendilerini daha az stresli ve daha emin hissettiklerini eklemişlerdir.

Anahtar Kelimeler: Çevrimiçi eğitim, hukuk öğrencileri, mesleki yabancı dil kursu, Covid-19 pandemisi 


\section{Introduction}

Until quite recently, online education was a topic of relevance mostly to those with a special interest in that area. But, with the sudden closer of schools and universities across the world because of COVID-19 pandemic, all teachers have been requested to deliver lessons in online platforms. According to Gonzalez and Louis (2018), online education is a type of learning, which is carried out from a distance and is supported by electronic devices such as computers, laptops, tablets, and smartphones, which all require internet connection to make distance learning possible. During the past decades, the use of computer and internet in educational setting has increased dramatically (Warschauer, 1996). Computers and internet in educational setting are known to help creating and increasing motivation, adapting learning to the learners, making experiential learning possible, offering authenticity, enhancing achievement, providing channels of communication, supplementing exercises and feedback, enabling individual and group projects, publishing student work, and finally enabling critical thinking skills (Ruschoff, 1997).

As stated by Yadov, Gupta, and Khetrapal (2018), the education field has seen significant changes over the last 20 years. Using the internet in education has many advantages, as seen in Fox (1998), Singhal (1997), and Warschauer (1996). Firstly, using internet is intrinsically motivating for students, since they see it as a trendy and useful tool, enabling them to be connected with the world and communicate directly, inexpensively, and conveniently with other learners round the clock, in school, at work, or at home. Secondly, using the internet is likely to give students control over their learning, enabling them to go at their own pace and choose their own paths according to their individual needs. Thirdly, the development of hypermedia within the context of the World Wide Web (WWW) offers a vast array of resources for both teachers and students to search and access authentic materials, from newspaper and magazine articles to radio broadcast and chat-rooms, and also to materials prepared specially for students. Apart from retrieving information from the internet, learners can also create their own materials, such as projects and share them with other participants in other classes or with public. This possibility also adds a great deal of interest, as students communicate with each other. In facing this digital era, most teachers are increasingly aware of the trend to incorporate and integrate computer and internet technology into their instruction. Wise (1996) pointed out that the internet has begun to have a significant role in education and has changed the nature of teaching and learning, because it provides students with a wide range of learning opportunities and experiences. Numerous resources on the internet offer considerable convenience and support to teachers in their profession. It is no wonder that more and more teachers have integrated the internet into their classrooms during the last decade (Fischer, 1999). Also, the development of new technologies and teaching methods gave new roles to the teachers. In this technology integration process, it is thought that technologies can take the place of teachers, but as Roe (1985) has pointed out, the original educational technology is the teacher's voice and it is still, potentially at least, the best. Volman (2005) offered five new roles of the teachers in internet-based classes as coach, instructor, trainer, advisor, consultant, and assessor. Volman (2005) also suggested that teachers intending to use internet in their classes, at first, should think about what is taught and what is learnt and then use it according to the learners needs. According to Warshauer and 
Healey (1998), teachers should take into consideration the needs of learners, design the teaching situations according to their needs and also, they should be trained to be able to use technology in their classes effectively.

Several research works have investigated the effectiveness of online teaching and learning (e.g., Chun, 1994; Kern, 1995; Khatoony \& Nejadmehr, 2020; Liu, 2005; Pop, 2010; Simsek, 2008; Sullivan \& Pratt, 1996; Wegner \& Holloway, 1999).

The study by Liu (2005) compared the effects of online vs. traditional instruction on students' learning and the results indicated the experimental group significantly outperformed the control group in most quizzes and the final test.

Pop (2010) utilized web tools in foreign language instruction and indicated that employment of new technologies besides increasing foreign language exposure and use, enhances the levels of students' satisfaction, motivation, confidence, and disposition which are crucial for communicative life-long foreign language learning.

Another study conducted by Simsek (2008) investigated the students' attitudes toward integration of Information Communication Technologies (ICTs) in a reading course. The findings indicated that the students were satisfied overall with the application of ICTs in their reading course and developed positive attitudes towards online course. Also, different studies by Chun (1994), Kern (1995), Sullivan and Pratt (1996) have shown that one of the effects of online discussion is a more balanced participation than in face-to-face discussion. Wegner and Holloway (1999) investigated the effects of distance learning on student achievement as well as the impact of distance learning on student attitudes concerning their learning experiences.

Khatoony and Nejadmehr (2020) examined the EFL teachers' challenges in the integration of technology for online classrooms and found that EFL teachers can perform the applications and platforms efficiently but yet there are many challenges such as lack of appropriate materials, lack of students' attention and their demotivation about online instruction, and finally lack of funding and support for language institutions.

\section{Methodology}

The participants in this study were 91 third-year and 86 fourth-year students (aged from 18 to 29) at Faculty of Law of Azad University in Iran, who were enrolled in 1-credit Professional Foreign Language Course 3 and 4 respectively in the fall semester of the academic year of 2020-2021. During their four-year education in BA, they should take four Professional Foreign Language Courses according to the university syllabus. In Professional Foreign Language Course, English Law texts and the related vocabularies are taught to the students. The rational for selecting third-year and fourth-year students was that they had the experience of face-to-face and online education for Professional Foreign Language Course and they could compare online and face-to-face instruction of this course. The convenience sampling method was used to select the participants of this study (Creswell, 2012). Convenience sampling is a method of collecting samples by taking samples that are conveniently located around a location or internet service. According to Creswell (2012), convenience sampling can offer useful information for producing enriched answers to the research questions of a study. 
To obtain a comprehensive understanding of the participants' perceptions about integrating technology and online education during Covid-19 pandemic and the perceived differences between face-to-face and online education, one open-ended questionnaire was emailed to all the participants of the study and they were required to write a self-reflection by answering the question of the questionnaire. From all participants of the study, 84 third-year students and 75 fourth-year students completed and returned the questionnaire by e-mail to the researchers of the study. To analyze the qualitative data obtained from participants selfreflections, however, content analysis was conducted. It is noteworthy to say that the participants self-reflections were written in Persian so all transcriptions were translated to English by the researchers of the study prior to the analysis. The recurring themes were identified and then analyzed. These themes were listed and grouped into similar categories which represented the participants perceptions about integrating technology and online education during Covid-19 pandemic and also their insights about the differences between face-to-face and online education. Additionally, peer debriefings were used to support the credibility of the analysis (Creswell \& Creswell, 2017). After analyzing the data, the recurring themes were checked by two expert colleagues from English Language Teaching Department who were not involved in this study, and based on their feedback some small changes were made.

\section{Findings}

This section involves the answers to the research question with the support of participants' excerpts. The only question of this study was "What are your perceptions about integrating technology and online education in Professional Foreign Language Course during Covid-19 pandemic?"

From the total of 159 students, 112 of them stated that online education is challenging for them.

Eighty-six of the participants stated that their first problem is that they are not able to rely on themselves in learning and understanding Law texts. They also mentioned that they have lack of confidence in their ability to do their assignments. The verbatim below best illustrates the related themes regarding lack of self-reliance and self-confidence:

"I cannot understand the instructions on my own, so I cannot do the assignments well. Law texts and vocabularies related to them are so difficult to be understood on myself. I think I need the instructor's help all the time (Excerpt 1)."

"Actually, I am not good in learning languages and I always have difficulty in understanding English texts especially Law texts. It takes me a lot of time to conduct the assignments and deliver them before dead line (Excerpt 2)."

Seventy-four of the students added that there is lack of immediate feedback from their instructor in order to understand whether they learned and understood the texts or not. The sample quotes for this problem are given below:

"I do not have sufficient contact with my instructor. During our online lesson, some of the students ask so many questions from him and there is not enough time for answering all the questions. I spend so much time to understand the texts on my own and if I cannot get 
feedback from my instructor immediately, I cannot find out whether I understood the texts or not and I get frustrated (Excerpt 3).”

"Absence of face-to-face contact with our instructor is a big problem. I cannot discuss my problems related to the lesson instantly in online platform and get feedback. After doing my assignments, I am not sure about them because I do not feel confident whether I did them correctly or not (Excerpt 4)."

Fifty-one of the students said that when they study online, they are distracted by phone or other online activities such as instant messages from Facebook or WhatsApp. Some of them said that they cannot concentrate on the lesson while they are studying by online education. The sample statements for lack of concentration because of distraction by phone and other online applications are given below:

"I do not have access to laptop or computer so I use my smartphone for attending online classes and sometimes the messages from my Facebook account or WhatsApp distracts me and I cannot concentrate on my lesson (Excerpt 5).”

"The only device which I have for participating in online classes is my smartphone and because I work and I get online orders for supermarket, most of the times my phone rings and I cannot focus appropriately on my lesson (Excerpt 6)."

Forty-nine of the students stated that they cannot adapt to the online learning situation because they often face with technical problems during online lessons and they cannot solve the problems or manage online learning tools by themselves so they cannot keep up with the class. The sample statements for not being able to adopt to online education because of technical problems are given below:

"Sometimes, when our online class starts, I face technical problems for example poor internet connection or power failure because I live in a small village and due to these problems especially low-speed internet connection or inadequate internet quota I cannot attend my online classes (Excerpt 7)."

"I do not have smartphone and my laptop is also very old and it does not work appropriately sometimes. Furthermore, I am not good in working with different applications. Therefore, I cannot take part in my classes on time and when I join the class in the middle of the lesson, it becomes so difficult for me to keep up with the class. So, I do not understand the initial instructions about activities and the Law text which are taught (Excerpt 8)."

Twenty-five of the students mentioned that they cannot have group work so they cannot complete their assignments on time in online education. They discussed that before online education, they always asked help from their classmates when they had problems in understanding and doing the activities and assignments. The sample statements for not being able to have group work are given below:

"I and my friends were staying at the dormitory before Covid-19 pandemic and we always did our assignments together. Whenever we had problem in understanding the instructions or doing homework, we helped each other. Now, we have WhatsApp groups and we can discuss the problems but it is not beneficial enough (Excerpt 9)." 
"Group works are very important in studying our Professional Foreign Language Course because the texts related to different subjects of Law are so difficult to be understood. In my opinion, group work should be face-to-face in order to be effective (Excerpt 10)."

Sixty-six of the students declared that they are interrupted by family members while online education. The sample statements for being interrupted by family members are given below:

"My family expects me to help them in house chores or work in our family work place instead of taking part in my online classes. They think that I can attend my online classes whenever I want (Excerpt 11).”

"All of my siblings are students and they distract me while I have online classes. Most of the time, they deliver their lessons to their teachers with loud voice or when they want to do their homework or be prepared for their lessons, they ask me to give them my laptop. Understanding the difficult Law texts using smartphone is not possible because sometimes I lose the lines because I cannot see and recognize the words or I can be distracted by messages or calls (Excerpt 12)."

Seventy-eight of the students who participated in this study said that they are full of stress due to Covid-19 pandemic so they cannot focus on their lessons. They stated that all the time they are thinking about the disease and have the fear of losing their family members. Because all of the students of this study are living in Gilan Province in Iran which witnessed a high number of deaths from the beginning of the Covid-19 pandemic. From these seventyeight participants eight of them stated that they lost one of their family members because of Covid-19 pandemic. The sample statements for having stress of losing family members are given below:

"I always have stress of losing my parents because both of them have heart disease and also my father had a heart operation three years ago. They are in high-risk groups and this stresses me a lot (Excerpt 13).”

"I lost my father six months ago because of Covid-19 and this bothers me. I am the oldest one in my family and my brothers are primary school students. I always have stress for the future and I cannot focus on my lessons (Excerpt 14)."

Thirty-one of the students also mentioned that financial problems which they faced during Covid-19 pandemic made them stressful too. They said that they are from low-income families and they or their families lost their jobs and now they have no financial support. The sample statements for being stressful because of financial problems are given below:

"Before Covid-19 pandemic I was working in a restaurant and I could earn a small amount of money to buy my books or internet quota for my phone but after arising of Covid19 pandemic I lost my job. Now, I got stuck in a difficult situation because of financial problems (Excerpt 15)."

"I and my family had a small work place in district bazaar and we were selling vegetables and fruits there. But by existing of Covid-19 pandemic and quarantine, we cannot earn enough money. I am very stressful because I cannot buy my books and even, I cannot 
make a photocopy of them so I study all my lessons from my smartphone and this is very difficult for me (Excerpt 16)."

From the total of 159 students who participated in this study, 47 of them said that they are pleased of online education and integrating of technology into Professional Foreign Language Course.

Twenty-six of them explained that it was a positive experience for them. They said that by online education they do not waste their time commuting to the university every day or they do not waste money for staying in a dormitory or hiring a house. These can be well exemplified in the verbatim statements below:

"Before, I had to commute to the university from my city four days a week which was very time consuming. Now, I attend my classes from my home and I am very satisfied (Excerpt 17)."

"Before Covid-19 pandemic, I spent a lot of money to hire a house and now I save this money for my MA education and I am very happy for that (Excerpt 18).”

Eighteen of the students also said that they are pleased of online education because they have more contact with their instructor. The sample quotes for this statement are given below:

"Before online education we had contact with our instructor only during the class hour but now we can ask our questions or get feedback by sending messages from WhatsApp or emailing him 24 hours a day (Excerpt 19)."

"In our traditional class, we never had sufficient time for asking all the questions but now in online course, we can write our questions in chat box and our instructor answers them even after class (Excerpt 20)."

Seventeen of the participants stated that online education has brought some technological facilities to the course too. The sample statements for this are given below:

"Before, the students were not allowed to use their smartphones in the class for looking at vocabularies' meanings from online dictionaries but now by online education it is possible (Excerpt 21)."

"In online education we can have discussion in the chat room about the problems that we face while studying texts in online course. Even we can have audio discussion using WhatsApp when we do not understand or miss a part of the text (Excerpt 22).

Nine of the participants of this study also explained that they feel stress-free and confident while attending online course. The sample statements for feeling stress-free and confident are given below:

"In fact, I am very stressful person but this online course gave me self-confidence because I can ask and answer questions and can have interaction with my classmates and my instructor without any stress (Excerpt 23)." 
"Before online education, I was a very shy person and I was ashamed of asking the questions from our instructor or I was not able to answer the questions appropriately. But now I feel myself very confident during my online course (Excerpt 24).”

Twenty-seven of the participants stated that they feel themselves more independent learners. The sample statements for this are given below:

"In our traditional class, I was not able to rely on myself but in online education I can say that I started to become an independent learner. Now, I try to understand the activities and instructions by looking at different online or paper dictionaries and also, I can understand the texts too (Excerpt 25)."

"During online education I found out that I can rely on myself. I understood that if I try, I can study Law texts and do my assignments on my own (Excerpt 26).”

Table 1 depicts the frequency of all participants' perceptions about integrating technology and online education in Professional Foreign Language Course of Law Department in one of Azad Universities in Iran during Covid-19 pandemic. The perceptions of participants in Table 1 were divided into two types: (1) Negative attitudes and (2) Positive attitudes also, they were written from the most frequent one to the least frequent one.

Table 1

Students Perceptions about Integrating Technology and Online Education

\begin{tabular}{|c|c|c|c|c|c|}
\hline Negative attitudes & $\mathbf{N}$ & $\%$ & Positive attitudes & $\mathbf{N}$ & $\%$ \\
\hline Online education is challenging & $\underline{159}$ & $\underline{77}$ & Online education is satisfying & $\underline{47}$ & $\underline{23}$ \\
\hline -Lack of self-reliance and self-confidence & 86 & 47 & -Being independent learner & 27 & 13 \\
\hline -Being stressful about losing family members & 78 & 37 & -Not wasting time and money & 26 & 12 \\
\hline $\begin{array}{l}\text {-Lack of immediate feedback from the } \\
\text { instructor }\end{array}$ & 74 & 35 & -Having more contact with the instructor & 18 & 9 \\
\hline -Being interrupted by family members & 66 & 32 & $\begin{array}{l}\text {-Bringing some technological facilities to the } \\
\text { course }\end{array}$ & 17 & 8 \\
\hline $\begin{array}{l}\text {-Lack of concentration because of distraction } \\
\text { by } \\
\text { phone and other online applications }\end{array}$ & 51 & 24 & -Feeling stress-free and confident & 9 & 4 \\
\hline -Having technical problems & 49 & 23 & & & \\
\hline $\begin{array}{l}\text {-Being stressful because of financial } \\
\text { problems }\end{array}$ & 31 & 15 & & & \\
\hline -Lack of group work & 25 & 12 & & & \\
\hline
\end{tabular}

\section{Discussion}

This study aimed at figuring out the Law students' perceptions about integrating technology and online education in Professional Foreign Language Course during Covid-19 pandemic. These students were asked to explain their perceptions about the differences between face-to-face and online education in this course. The content analysis of the qualitative data illustrated that students (77\%) reporting negative attitudes about their online education in Professional Foreign Language Course believe that online education is challenging for them. It was revealed that $47 \%$ of these students have lake of self-confidence and self-reliance during online education. They mentioned that they cannot understand the difficult Law texts without the help of their instructor and are not able to rely on themselves in 
doing their assignments. Some of the students (37\%) expressed that they cannot adopt to online education because they always have stress of losing their family members. So, they cannot concentrate on their education. From these students, about eight people said that they had lost one of their family members during Covid-19 pandemic and they have the stress of losing another family member. About $35 \%$ of the students also stated that they cannot get immediate feedback from their instructor while they are on online education. They expressed that in face-to-face education they could ask their questions and talk about their problems whenever they and their instructor attend the university. But now they cannot visit their instructor because of the closer of the universities. They also said that although they get feedback for their assignments from their instructor, yet they are not able to understand some parts of the texts. So, some problems remain vague for them. About $32 \%$ of the students who had negative attitudes toward online education expressed that they are always interrupted by their family members while their online lessons. Some of these students mentioned that their home is not appropriate for online education. For example, some of them said that they do not have a private room of their own or some others stated that they have crowded family and they cannot ask all the family members to be silent during their lessons. The other one who had two small children said that I do not have any one in a city where I live to take care of my children while I am taking part in my online lessons. About $24 \%$ of the students reported that they cannot focus on their online lessons because of distraction by their phone or other online applications. Some students explained that they are also working online from home and they have to answer the phone or the messages from WhatsApp so they cannot turn off their phones while attending online lessons and this causes distraction. Students (23\%) also complained about technical problems that they face during online lessons. Most of these students reported that they do not have access to high-speed internet connection so they follow online lessons with frequent internet connection cut offs and this situation leads to not being able to understand the lessons. Some students also expressed that they do not have sufficient money to buy a new laptop or smartphone and their old equipment are not appropriate for online education. About $15 \%$ of the students who had negative attitudes towards online education also explained that they are stressful because of their financial problems. Some of them said that they cannot focus on their lessons because they are always dealing with seeking jobs to earn money to make a living. They added that before Covid-19 pandemic, they were working in their family's work place or they had their own job (e.g., working in restaurants, shops, courses, etc.) and they could make money to defray their university expenses. But now most of the work places are closed down and the people working in these places are unemployed. Finally, about $12 \%$ of the students with negative attitudes about online education reported that they cannot have appropriate group works. They said that before Covid-19 pandemic, they could gather in cafes or in a library to do their assignments and projects together but now although they have WhatsApp groups and they can discuss through WhatsApp, it is not efficient and sufficient.

Although some students described that online education was challenging, some other students explained that it was satisfying experience for them. The findings of the content analyses of Law students' perceptions about integrating technology and online education in Professional Foreign Language Course during Covid-19 pandemic displayed that from 206 
participants only 47 student $(23 \%)$ had positive attitudes toward online education and were satisfied about this situation. About $13 \%$ of these students reported that they became independent learners by help of online education. Most of them said that they were always dependent on their instructor and did not accept that if they tried, they could do their assignments themselves. But, after putting all people in quarantine in Iran and because the universities online education platforms were not ready, they started to try to study and do their assignments on their own. Little by little, they changed from dependent learners to autonomous learners. About $12 \%$ of students with positive attitudes towards online education expressed that using technology and internet for learning and teaching provided some positive conditions for them such as saving time and money. Some of them mentioned that expenses of studying at the university is high especially if you are not studying in a city where you live and some people cannot afford the expenses such as rent, tuition of the university and so on. Therefore, online education supplied them a good condition and they can save their money. Nine percent of the students also stated that through online education they can have more contact with their instructor. They added that they can ask their questions by means of WhatsApp or e-mail from their instructor 24 hours a day even at the weekends. About $8 \%$ of the students with positive attitudes towards online education reported that this situation brought some technological facilities to the course. They said that in some conditions our instructor uses hypertexts in order to teach us difficult Law texts in online education. When he finds out that we have difficulty in understanding of some parts of the Law texts, he opens hypertexts related to our lesson in English and Persian and explains the texts using these hypertexts. By this method, we can understand the Law texts better. Also, some of the students explained that in online education we can look up the meaning of the vocabularies by using online dictionaries on our smartphones that we never had permission to use in our traditional classes. Only 4\% of the students with positive attitudes towards online education reported that they feel stress-free and confident while attending online lessons. They stated that online education provided them a relaxing condition at home and they are now more confident about their answers to assignments and they also answer all the questions without any problem.

\section{Conclusion}

Based on the findings, this study concluded that integrating technology and online education in Professional Foreign Language Course during Covid-19 pandemic had some positive and negative results for the students of Law Department. The majority of the students who participated in this study had negative attitudes towards online education. As we know, online education is a new way of instruction and delivering courses in countries like Iran. Before Covid-19 pandemic, all the university courses in Iran were delivered face-to-face and in traditional classes. So, it is somehow difficult for students and also instructors who have traditional perceptions of learning environments to adapt to new situation and methods of education.

While online education was challenging for some students of Law Department, it was satisfying experience for the other students of this department. These students benefited from online education which triggered by Covied-19 pandemic nine months ago. For them, this was 
a new and advantageous situation and they also discovered some of their abilities owing to online education.

Considering the findings of the study, it can be said that every new experience can be challenging at first for all students and instructors. The sudden shift to online education because of Covid-19 pandemic was unpredictable situation and all students and educational staff were in a big shock. Most of the schools and universities were not ready for this situation and also most of the instructors had never taken part in any online education. The families encountered with the biggest shock. They had to provide all the supplements that were required for getting online education for their children such as internet connection at home, laptops, personal computers, smartphones, and so on. All these caused a lot of problems for all people around the world and also in Iran. To deal with these problems took a lot of time and energy. In addition, the fear of the Covid-19 Virus was also another challenging problem. But gradually most of these problems were solved and now the students and instructors are getting adapted to new situation and way of teaching step by step.

The results of this study were consistent with the result of a recent study done in Pakistan by Adnan and Anwar (2020) on higher education students towards compulsory online education in university courses during COVID-19 pandemic which reported that online education is not as effective as traditional classes. Also, a study conducted by Moralista and Oducado (2020), determined the perception of 27 faculty members towards online education in a State College in the Philippines. The results obtained from this study showed that the majority of faculty members had intermediate computer competency and had no training and experience in online teaching, and only a few of them had a very stable internet connection. These faculty members reported that online education results in more academic dishonesty, impersonal and lack feeling compared to traditional face-to-face classes, and also difficult to accomplish in terms of technology.

However, our study' results were different from those of some other studies (Muthuprasad, Aiswarya, Aditya, \& Jha, 2021; Rajab, Gazal, \& Alkattan, 2020) which were conducted recently and during Covid-19 pandemic. In a study on Medical students in Saudi Arabia, the results revealed that online education has a largely positive impact on Medical education (Rajab, Gazal, \& Alkattan, 2020). Also, in another study conducted in India, the students stated that flexibility and accessibility of online education makes it attractive, but in rural areas connectivity problems makes it a challenge for students. However, in Agricultural education where many courses are practical, shifting totally to online education may not be possible (Muthuprasad, Aiswarya, Aditya, \& Jha, 2021). 


\section{References}

Chun, D. (1994). Using computer networking to facilitate the acquisition of interactive competence. System Journal, 22(1), 17-31.

Creswell, J. W. (2012). Educational research: Planning, conducting, and evaluating quantitative and qualitative research (4th ed.). Boston, MA: Pearson.

Creswell, J. W., \& Creswell, J. D. (2017). Research design: Qualitative, quantitative, and mixed method approaches (5th ed.). Thousand Oaks, CA: SAGE Publication

Fischer, R. (1999). Computer applications and research agendas: Another dimension in professional advancement. CALICO Journal, 16, 559-571.

Fox, G. (1998). The internet: Making it work in the ESL classroom. The Internet TESL Journal, 4(9).

Khatoony, S., \& Nezhadmehr, M. (2020). EFL teachers' challenges in integration of technology for online classrooms during Coronavirus (COVID-19) pandemic in Iran. AJELP: Asian Journal of English Language and Pedagogy, 8, 1-16. https://doi.org/10.37134/ajelp.vol8.sp.1.2020

Gonzalez, D., \& Louis, R. St. (2018). Online Learning. In J. I. Liontas (Ed.), The TESOL Encyclopedia of English Language Teaching (1st ed.). https://doi.org/10.1002/9781118784235.eelt0423.

Kern, R. (1995). Restructuring classroom interaction with networked computers: Effects on quantity and quality of language production. The Modern Language Journal, 79(4), 457476.

Liu, Y. (2005). Effects of online instruction vs. traditional instruction on students' learning. International Journal of Instructional Technology and Distance Learning, 2(3), 57-65.

Moralista, R., \& Oducado, R. M. (2020). Faculty Perception toward Online Education in a State College in the Philippines during the Coronavirus Disease 19 (COVID-19) Pandemic. Universal Journal of Educational Research, Horizon Research Publishing Corporation (HRPUB), 8 (10), 4736 - 4742.

Muthuprasad, T., Aiswarya, S., Aditya, K. S., \& Jha, G., K. (2021). Students' perception and preference for online education in India during COVID -19 pandemic. Social Sciences \& Humanities Open, 3.

Pop, A. (2010). The impact of the new technologies in foreign language instruction our experience. Procedia Social and Behavioral Sciences, 2, 1185-1189.

Rajab, M. H., Gazal, A. M., \& Alkattan, K. (2020). Challenges to online medical education during the COVID-19 pandemic. Cureus, 12 (7). https://doi.10.7759/cureus.8966

Roe, P. (1985). Making IT available. In R. Qurik \& H. G. Widdowson (Eds.), English 
in the world: Teaching and learning the language and the literature (pp. 68-

81). Cambridge: Cambridge University Press.

Ruschoff, B. (1997). Technology enhanced resources and information technology in language learning. Language Teaching Journal, 30, 226-242.

Simsek, S. (2008). Students' attitudes towards integration of ICTs in a reading course: A case in Turkey. Computers \& Education, 51, 200-211.

Singhal, M. (1997). The internet and foreign language education: Benefits and challenges. The Internet TESL Journal 3(6).

Sullivan, N., \& Pratt, E. (1996). A comparative study of two ESL writing environments: A computer-assisted classroom and traditional oral classroom. System Journal, 24 (4), 491501.

Volman, M. (2005). A variety of roles for a new type of teacher educational technology and the teaching profession. Teaching \& Teacher Education, 21, 15-31.

Warschauer, M. (1996). Computer-assisted language learning: An introduction. In S.

Fotos (Ed.), Multimedia language teaching (pp. 3-20). Tokyo: Logos

International.

Warschauer, M., \& Healey, D. (1998). Computers and language learning: An overview. Language Teaching 32, 57-71.

Wegner, S., \& Holloway, K. (1999). The effects of a computer-based instructional management system on student communications in a distance learning environment. Educational Technology \& Society 2(4).

Yadov, N., Gupta, K., \& Khetrapal, V. (2018). Next Education: Technology Transforming

Education. South Asian Journal of Business \& Management Cases. https://doi.org/10.1177/2277977918754443. 